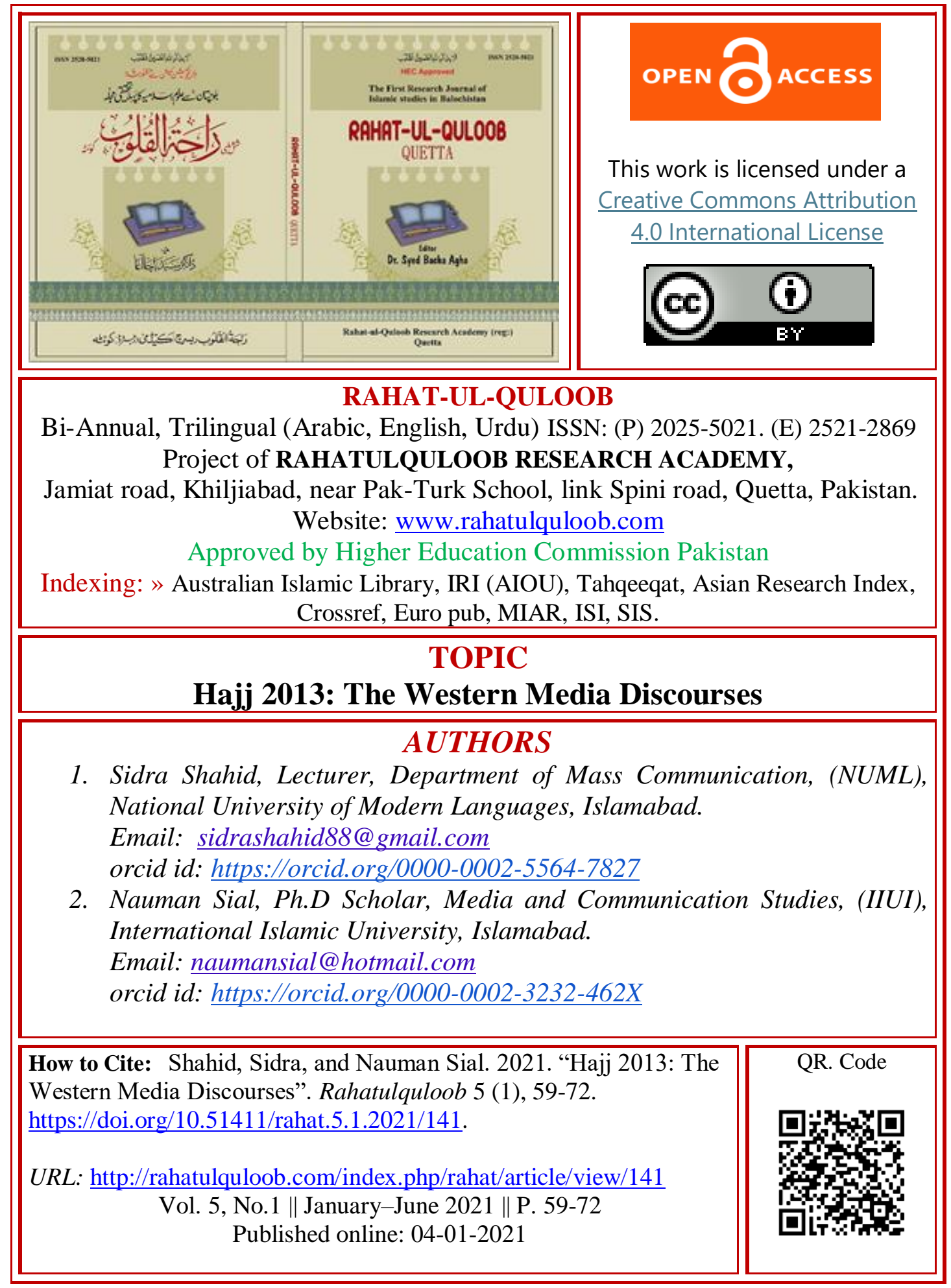




\title{
Hajj 2013: The Western Media Discourses
}

\section{ABSTRACT:}

\author{
${ }^{1}$ Sidra Shahid, ${ }^{2}$ Nauman Sial
}

Hajj is the fifth pillar of Islam and is the largest religious gathering on the globe. Every year, over two million Muslims make their way to Mecca to perform Hajj. The current study attempted to explore the themes that were dominant in the print media discourses of United Kingdom and United States about holy event Hajj. The study also tried to find out that how the Western print media constructed the identity of Muslims holy event. The qualitative discourse analysis has been used as a research design for this study. The two UK English dailies i.e. Daily Mail and The Guardian, and one online news publication IBTimes while two US English dailies i.e. Los Angeles Times and USA Today, and one online publication Huff Post have been selected for this purpose. A total of 20 news items from the year 2013 have been selected for the analysis. The results indicated that there was no significant difference in the assortment of themes by print media of UK and US. The Western media used the discourses of sectarianism and terrorism, and also highlighted the issues of Muslim sects. The results also revealed that the Western newspapers presented the importance of Hajj, but they also associated the gathering of Muslims with fears and threats.

Keywords: Hajj, Pilgrims, Western Media, Discourse Analysis, MERS-CoV Introduction:

The religion of Islam is based on five pillars. These pillars provide the very basic framework of being a Muslim which includes the acknowledgment of faith i.e. kalama tayyaba, to offer prayers five times a day, fasting during the month of Ramadan, to give Zakat to poor and needy people, and to visit to the holy city of Mecca that also known as Hajj. ${ }^{1}$ Hajj is the biggest religious congregation of mankind over the globe that draws Muslims from over hundred countries. Each year, over two million Muslims who own enough financial resources as well as physically able usually make their way to Mecca to perform Hajj. ${ }^{2}$ Islam gives importance to individual as well as communal worship of one God. Hajj is basically a collective practice of faith that gives value to collective rituals. ${ }^{3}$ Hajj is the social act of worship, and it has great importance both spiritually and socially. It is a collective effort in which Muslims fill up with the obligation or embark on the devotion willingly that seek to be at the same time and place to practice the same set of rituals. ${ }^{4}$ The fifth pillar of Islam marks the performance of specific actions (rituals) at specific places during the last lunar month i.e. Dhu alHijjah. These rituals used to perform as they have explained in the Holy Quran (2:196-203, 3:96-97, 22:26-30), and the sunnah of Holy Prophet Hazrat Muhammad (PBUH). The Hajj rituals intend to honor certain trials faced by Prophet Ibrahim, his wife Hajar, and their son Prophet Ismail ${ }^{5}$. The significance of Hajj appears in these words in Holy Quran: "Indeed, the first House [of worship] established for mankind was that at Makkah-blessed and a guidance for the worlds. In it are clear signs [such as] the 
standing place of Abraham. And whoever enters it shall be safe. And [due] to Allah from the people is a pilgrimage to the House - for whoever is able to find thereto a way. But whoever disbelieves - then indeed, Allah is free from need of the worlds". 6

Labayk Allahuma Labayk! Labayk, La Shareeka laka Labayk, Innal hamda wannimata laka wal mulk, La shareeka Lak! (transl. Here I am at your service, oh Lord, here I am! Here I am, No partner do you have - here I am, Truly, the praise and the favor are yours, and the dominion, No partner do you have!). Every year, during Hajj, millions of people chant these words in a single voice assembled at a place from different parts of the world. ${ }^{7}$ In Islam, Hajj is regarded as the spiritual peak in a Muslim's lifetime. The time period for Hajj is five days, which starts from $9^{\text {th }}$ Dhu Al-Hijjah to $13^{\text {th }}$ Dhu Al-Hijjah, i.e. the last month of Muslim calendar. There are about 1.6 billion Muslims i.e. $23 \%$ of the world population that makes Islam the second largest religion in the world. ${ }^{8}$ Ibn Battuta, a famous Muslim explorer documented that during Hajj, Muslims from different schools of thought worship collectively, this practice leads to integration of sacred routines ${ }^{9}$. The purpose of Hajj is to disengage human beings from their homes and to bring them to Islam's native land, and to stress the equality of all communities before God. Many pilgrims on their return from Mecca relate that the Hajj motivates a sensation of unity and harmony among international Muslim society. ${ }^{10}$

A study explored the impact of Hajj on pilgrims' lives. The study revealed that the Muslims event Hajj encourages tolerance, impartiality, and accord among believers. In longer effects, it brings a sense of openness in Muslim population. The study affirmed that the Hajj increases belief in equality and harmony among ethnic groups and Islamic community as well as among adherents of different religions. It also leads to more favorable approach toward women, and confronts the notion of the West that Islam and radicalism are interlinked. ${ }^{11}$ Another study examined the influence of social and psychological factors on Hajj crowd. During the big gatherings, it becomes imperative to focus on crowd behavior. The role of emotional and social factors could be very important that might influence the way masses react, especially when religious events like Hajj take place. ${ }^{12}$ Some data could be found which states that crowd behavior and movement during the Hajj used to be fairly distinct in a sense that they involve fixed rituals that need to be performed at exact hours and days at specific locations ${ }^{13}$. In 2012, almost 12 million pilgrims visited Mecca for the purpose of Hajj and Umrah. The financial specialists estimated that the revenues of Hajj and Umrah were $10 \%$ more as compared to the year 2011, which reached to over 62 billion riyals ( $\$ 16.5$ billion). The overall income from Hajj also represent three percent of the Saudi Arabia's gross domestic product (GDP). ${ }^{14}$

The United States television channel Cable News Network (CNN) for the first time in 1998 provided live coverage of Hajj 1419 Hijri directly from Mecca and Arafat. ${ }^{15}$

There is an old saying regarding Hajj, "Before you visit Makkah it beckons to you, and when you leave it behind it calls to you forever". ${ }^{16}$ Isha Sesay shared her experience of covering Hajj 2007 as a CNN reporter. She was of the view that after covering 
Hajj, her brain was plagued by the purity and supreme demonstration of Hajj. She again covered the holy event in 2009 and also stated, "It struck me that to successfully perform the Hajj you must give yourself over entirely to it". ${ }^{17}$ In the light of this background information, the current study attempts to explore the themes that are dominant in the print media discourses of United Kingdom and United States about Muslims holy event Hajj. The study would also try to find out that how the Western print media construct the identity of holy event Hajj and how do these constructions promote or undermine the purity of the event.

\section{Literature Review:}

The perception of the world in the minds of people is not a reality; rather this image is decorated by media in human brains. ${ }^{18}$ Through media, people form reflection of other countries and cultures. Most people rely for information solely on media and they don't have access to other sources. Numerous studies verified the influence of mass media on its viewers. Cohen stated, "the world will look different to different people, depending not only on their personal interests, but also on the map that is drawn for them by writers, editors, and publishers of the papers they read". ${ }^{19}$ When the news media give priority to a story, so it becomes more prominent in the minds and conversation of its consumers, and could be regarded as an important issue. As time passes, agenda endorsed by any medium turns into public agenda, and it is the media holder who decides which information needs to be covered, and which needs to be overlooked ${ }^{20}$ A study observed the association that either print media reporting and public perceptions are reciprocal entities. The study concluded that they influence over one another. ${ }^{21}$ The profitable media organizations look for their own benefits. They present the reality to the world according to the communal, political and financial benefits of the leading states of the world. People only expose to the information that media wants them to see. Consequently, the media plays role in mobilizing the audience to embrace the social and financial gains of the influential groups. ${ }^{22}$ The role of mass media is significant in creating national identities. Belief is an entity which holds a nation together. These beliefs communicate over the globe by means of cultural artifacts including print and electronic media. So it could be stated that news discourses have influence over fabrication of national identities of different nations. ${ }^{23}$ Though, it is also obvious that, "the news does not reflect or construct the world truthfully; rather it constructs the world in such a way as to conform to an image shaped by partial interests - typically those of the powerful". ${ }^{24}$

A number of techniques use to exploit any news and to create general opinion about it. The information is downplayed, and the West has exploited it very effectively. During the Indonesian mass killings of 1965, the Indonesian forces were skilled and backed by Central Intelligence Agency (CIA). Nearly, half a million citizens were killed in this massacre to gain political success. It could be regarded as one of the most notable event of brutality that needed to be covered. But after three months, Time magazine discussed the story. Even The New York Times also took one month 
more to discuss the issue. In fact, when only omission doesn't enough and news manages to reach the masses, the media starts frontal attack to discredit the story. Also, with regard to 'positive and negative labeling', the US media uses positive labels such as stability, leadership, strong defense, and healthy economy, and uses negative labels as leftist guerrillas, conspiracy theories, inner-city gangs, civil disturbances, and Islamic terrorists. ${ }^{25}$ The Western media depends greatly on elite information sources, and contribute in propaganda campaigns that support elite interests. ${ }^{26}$

The stress of Western media that Muslims are extremists is result of notions of clash of civilization where one is not ready to acknowledge the existence of others. This clash of civilization brings disintegration in the world. The conflict between the West and Islam has been centuries-old, and is unlikely to reduce. And this military interaction could become more hostile. ${ }^{27}$ The US media treatment inclines to expose Islam in terms of clash of civilizations which highlights the differences among both. These differences portray West in terms of culture and Islam as a religion. The study indicated that Muslims didn't consider the apprehension as religiously, rather they considered it as a political issue. Such distorted coverage of Islam hurts the sentiments of Muslims everywhere. Arab world is of the view that the U.S. media fully focuses on presenting Islamic nations as breeding lands of aggression and brutality. The US media also not highlights the modest happenings that occur in most of the Islamic countries. ${ }^{28}$ Terrorism can be defined as, "the premeditated use or threat of use of violence by individuals or subnational groups to obtain a political or social objective through intimidation of a large audience beyond that of the immediate victims". ${ }^{29}$

After the attacks of 9/11, then US president George W. Bush advocated special 'war on terror' discourses, and which were promoted brusquely by the media. Bush stated, "You're either with us, or against us". Bush's war on terror provided a clear distinction between good and evil, us and them. This twofold discourse of good against evil postulated that 'we' are the good and the 'other' is evil. This philosophy created a global dilemma that 'we' associates to all 'good' acts, and 'other' associates to all the 'negative' deeds. ${ }^{30}$ The shortest account of political Islam is that it represents 'Islam used to a political end.' The other terms that used by the West such as 'radical Islam', 'extremist Islam', 'militant Islam', 'Islamism', 'fundamentalist Islam', and 'revolutionary Islam.' This diversity in referring to the terms points out toward many other aspects of the political Islam which judged by the Western forces. The revival of Islam, generally referred to as 'political Islam', marked the start of an Islamic restoration that challenged the authoritarian regimes in the Middle East. The ideological roots of this resurgence dates back to the development of the Muslim Brotherhood in 1928 in Egypt. Within the short period of time, Muslim Brotherhood became an important religious and political force ${ }^{31}$. A study analyzed the media reporting and public opinion of nine overseas nations in UK and US print media. They selected one newspaper from both countries i.e. The New York Times and The Times from US and UK respectively. The results indicated that negative interpretation of countries resulted in negative opinion 
of a particular country by the readers whereas only marginal associations highlighted between neutral and positive media frames of any specific country and public opinion. ${ }^{32}$ The notion of Islamophobia prevalent in the Western society is somehow the result of imprecise and unfair reporting of the West about Islam. The audiences perceive news programs as true because reporting is considered as objective and fair. Though, during the analysis of the 2002 Turkish elections in the UK and US newspapers, the striking outcomes revealed as the political coverage lacked the context. ${ }^{33} \mathrm{Al}-\mathrm{Zahrani}$ investigated the coverage of Islam and Muslims in the print media and television of US. The study observed the coverage of news channel i.e. ABC (American Broadcasting Company) News, and one newspaper i.e. The New York Times. The study concluded that the treatment of Islam was unconstructive as West highlighted only demoralizing proceedings. ${ }^{34}$ The West don't use the expression Islam distinctly, rather they use it as a tag, a representation of vicious group. ${ }^{35}$

A study explored the portrayal of Islam in the US television talk shows of Fox News and CNN. The study showed that the talk shows of both US channels were biased with regard to the selection of subjects, participants and comments. The constructive references of Muslims and Islam were almost insignificant. They argued that these talk shows portrayed Islam as a religion of propagating culture of violence. ${ }^{36}$ Khalid observed the image of Muslim world in the US mass media. For this purpose, the study analyzed the coverage of six Muslim countries in four US newspapers. The results supported to the propaganda framework which maintained that hostile issues appeared more attractive to the audiences in contrast to the peaceful and positive developments. ${ }^{37}$ Another work examined the portrayal of Muslims in two US magazines i.e. Newsweek and Time. The study analyzed the coverage of twelve Muslim countries in these magazines. The results revealed that the representation of all Muslim countries by both the magazines were negative as compared to positive representation. Also, the language of the articles was offensive as well as strong verbs and superlatives were used to establish the image of Islam. ${ }^{38}$ Ridouani stated, "whether they are televised or printed, it is not surprising that Western media reports maintain a constant distorted image of Arabs and Muslims. Fabricated stereotypes of Islam are omnipresent in Western media through all means of communication". ${ }^{39}$ From time to time, the Western media has labelled Muslims as intolerant, fanatical, fundamentalist, militant, alien and misogynist. ${ }^{40}$ After the attacks of $9 / 11$, mainstream US media featured in their headlines as, 'Yes, This is About Islam', 'This is a Religious War', 'The Revolt of Islam', 'The Deep Intellectual Roots of Islamic Terror', 'Muslim Rage', and 'Jihad 101'. ${ }^{41}$

\section{Theoretical Framework:}

The theory of framing has been used as a theoretical framework for this study. The concept of framing was given by Erving Goffman in 1974. Framing focuses not on which topics or issues select for coverage by the news media, but instead on the particular ways those issues present. ${ }^{42}$ The theory of framing is also known as secondorder agenda setting. The first order deals with the object level or "what to think 
about.' But second-order deals with attribute level or 'how to think about' ${ }^{43}$ Framing means choosing and making prominent aspects of the issues or events, and to make relation among them in order to promote a specific interpretation, assessment or solution. Framing can be positive or negative. It depends on the ways the information is disseminated. There are several interests of various groups like policy makers and journalists who have their own influences in framing different contents of the media. ${ }^{44}$ Media builds up social reality by "framing images of reality in predictable and patterned ways". ${ }^{45}$ Framing is reproduced as a procedure of promoting a narrative to explicit addressees which provide required explanations of an apparent reality by stressing on some features of the story and ignoring others, and establishing associations with them. Framing bias could take on three key meanings. Firstly, distortion bias which apply to news that purportedly distorts or falsifies reality. Secondly, content bias in which news favors one side instead of providing similar treatment to both sides. Thirdly, decision-making bias that motivates the journalists to produce the biased content. ${ }^{46}$ The media of the dominant nations conform and frame the news of other countries according to the interests of their states. The coverage of other countries in US media often frame according to the state policies toward other nations. ${ }^{47}$

\section{Research Questions:}

RQ-1: Which themes are dominant in the print media discourses of UK and US about Muslims holy event Hajj?

RQ-2: How do the Western print media construct the identity of holy event Hajj? And how do these constructions promote or undermine the purity of the event?

RQ-3: Does the use of vocabulary and slant about Hajj differ in UK and US newspapers discourses?

\section{Methodology:}

The qualitative discourse analysis has been used as a research design for this study. Discourse can be defined in three ways, "language beyond the level of a sentence, language behaviors linked to social practices, and language as a system of thought". 48 Discourse defines and produces the objects of human knowledge. It governs the way that a topic could be meaningfully talked about and reasoned about. It influences that how ideas put into practice and used to regulate the conduct of others. ${ }^{49}$ The rationale to apply discourse analysis is that it not only inspects the structure and composition of the news but it also links the language with social practices. The term discourse usually define in two ways: "a particular unit of language above the sentence" and "a particular focus on language use". ${ }^{50}$ The structure of discourse consist not only of text and dialogue; indeed discourse is an intricate communication process that also takes into account to a social perspective, and contributors usually involve along with production and reception processes. The 'production processes' take account of journalistic as well as financial and social practices of news making that play a significant role in the formation of media discourses. Also, the 'reception processes' include understanding, memorization and replication of information in the news. ${ }^{51}$ In terms of the study of 
message disseminated by the media, discourse analysis performs a significant role because of various possible developments that occurred within the field of discourse. The discourse analysis can be applied as a recognized and precise approach. In order to place discourse in the field of mass communication, it can be applied as a research model as it focuses on the study and analysis of text. ${ }^{52}$ Any kind of media plays a major role in shaping public opinion. The elite institutions aim to endure and replicate their dominance and social power by means of "privileged access to discourse and communication". 53

\section{Population and Selection of Sample Items:}

The population for this study is the news items that have been published in the print media of United Kingdom and United States of America regarding Islamic events. The two UK English dailies i.e. Daily Mail and The Guardian, while two US English dailies i.e. Los Angeles Times and USA Today have been selected for this purpose. Also, one online news publication of both UK and US i.e. International Business Times (IBTimes) and Huffington Post (Huff Post) has been chosen respectively. All the news items published in these six newspapers related to Muslims holy event Hajj has been selected from August 25, 2013 to November 25, 2013. The reason for selecting the year 2013 was that the first Hajj occurred after the Arab Spring in the Muslim countries ${ }^{54}$ and the Syrian Civil War was on peak in which more than one hundred thousand people had lost their lives. ${ }^{55}$ Also, the Middle East respiratory syndrome coronavirus (MERS-CoV) had spread in some nations of the world, and 74 cases with 39 deaths had been reported in Saudi Arabia. ${ }^{56}$ A total of 20 news items from these newspapers have been selected that fulfills the above criteria. The relevant data has been accessed from the online official websites of these papers. A single news item has been taken as a unit of analysis.

\section{Categories:}

This study is not aimed at presenting pilgrims feelings rather focuses on the covert motives of Western media that highlighted certain issues regarding Islamic event Hajj 2013. The categories are as follows.

*Name of newspaper. * Date of publication: To mention the publication date of the selected item. *Theme: Issue highlighted in an item. *Lines: Total space allocated. *Wordage: Total number of words written in selected item. *Slant: Positive, negative, neutral. *Style: Appreciating, reproving, criticizing, suggestive, illustrative or probing. *Adjectives: Specific terms that can be linked to any nation, individual, situation or event. *Metaphors: Words and terms applied to make some themes or issues well-known.

\section{Analysis:}

In order to study the Western media discourses regarding Hajj 2013, a total of 20 news articles selected from the print media of both United Kingdom and United States. A number of 12 relevant articles selected from two dailies and one online publication newspaper of UK i.e. Daily Mail, The Guardian and IBTimes. Also, 8 news items selected from two dailies and one online publication newspaper of US i.e. Los Angeles Times, USA Today and Huff Post. After going through the selected data, 
six themes were organized on which analysis was conducted which are as follows: 1).Number of Pilgrims, 2).Threat of Terrorism and Turbulence, 3).Effects of International Relations of Saudi Arabia, 4).Hajj Rituals, 5).MERS-CoV, 6).Hajj Management.

RQ-1: Which themes are dominant in the print media discourses of UK and US about Muslims holy event Hajj?

The themes that highlighted in the print media discourses of UK and US regarding Muslims holy event Hajj are as follows.

\begin{tabular}{|l|l|c|c|}
\hline S. & Themes & \multicolumn{2}{|c|}{ No. of Items in Newspapers } \\
\cline { 3 - 4 } No. & & $\mathbf{U}$ K & U S \\
\hline 1. & Number of Pilgrims & 5 & 3 \\
\hline 2. & Threat of Terrorism and Turbulence & 3 & 4 \\
\hline 3. & $\begin{array}{l}\text { Effects of International Relations of Saudi } \\
\text { Arabia }\end{array}$ & 3 & 4 \\
\hline 4. & Hajj Rituals & 3 & 3 \\
\hline 5. & MERS-CoV & 2 & 3 \\
\hline 6. & Hajj Management & 4 & 3 \\
\hline Total & & $\mathbf{2 0}$ & $\mathbf{2 0}$ \\
\hline
\end{tabular}

Table 1: List of Themes Highlighted by UK and US Newspapers

The results from Table 1 reveal that the print media of both UK and US gave almost equal coverage to main themes. All the six newspapers gave unusual importance to fewer numbers of pilgrims in Hajj 2013. In terms of threat of terrorism and turbulence, the Sunni Shiite conflicts, Muslim Brotherhood, and bloodshed in Syria was the focus of all papers. The daily and online publication newspapers also presented unparalleled importance to disunity among Muslim sects. With regard to the theme of international relations of Saudi Arabia, the papers presented tensions among Saudis and Iran. The theme of Hajj rituals was also presented mainly by Huff Post and IBTimes. The concerns of MERS-CoV and other chronic diseases was another prevailing theme. In terms of management, the Western print media endorsed the role of Saudi Arabian administration in taking different initiatives to avoid from any dreadful incident.

RQ-2: How do the Western print media construct the identity of holy event Hajj? And how do these constructions promote or undermine the purity of the event?

In the year 2013, Hajj drew fewer pilgrims as compared to previous years. These numbers went down by more than 20 percent for foreigners and 50 percent for Saudis because of health fears, and massive projects to increase the capacity of Grand Mosque of Mecca in coming years (Ministry of Religious Affairs, 2013). This issue was highly pointed out by both the Western media of UK and US. Los Angeles Times stated, "Fear of virus halves turnout of Muslim faithful for hajj pilgrimage", so that the Hajj 2013 concluded in a peaceful manner but number of pilgrims decreased to the highest extent. Huff Post published a story with the title, "Hajj virus concerns reduce Mecca Muslims pilgrims by one million." This story also highlighted the reasons of fewer 
Muslim pilgrims in 2013. With regard to threat of terrorism and turbulence, Huff Post mentioned that during Hajj sermon Grand Mufti Shiekh Abdul Aziz Al-Sheikh didn't openly talk about the ongoing tension among Arab countries; he only called for Muslims to unite. Los Angeles Times also reported that top Saudi cleric during his annual sermon gave a vague reference of Syrian civil war that dividing Muslims into different sects. Huff Post wrote, "In recent years, the Hajj also has reflected the concerns of unrest and bloodshed across the Arab world, including the civil war in Syria that has claimed more than 100,000 lives and sent millions of people fleeing across borders." They ruthlessly used the word sectarianism such as Sunni Salafis and Shiite Islamists in their discourses. In terms of the relations of Saudi Arabia with other nations, Daily Mail wrote, "Sunni Muslim Saudi Arabia not only hosts the pilgrimage but is also increasingly involved in the conflicts across the region. The kingdom is embroiled in a region-wide contest for influence with Shi'ite Iran, with each side accusing the other of backing Syria's bloody civil war." IBTimes wrote in a news story, "Egypt urges Saudis to deport Muslim Brotherhood supporters." The item stressed about the ongoing unrest and turbulence in the Egyptian state. The article stated that Egyptian authorities had concerns that Muslim Brotherhood supporters could demonstrate protests during the Hajj to mark a blot in Saudi-Egypt relations. In addition, Huff Post and IBTimes gave extensive impartial coverage to the event while reporting about the history and facts of Hajj. The Western print media readily covered the rituals of Hajj 2013 in their discourses with neutral notions. However, Western newspapers linked the slaughtering of animals with fatal diseases. Daily Mail claimed that MERS-CoV was linked with camel slaughter which is a part of Hajj rituals. The paper stated that when so many camels slaughter at a time, so it could cause eruption of potentially lethal infections. Los Angeles Times reported that less number of Muslims took part in the Hajj 2013 due to MERS fears that could spread among the throngs of faithful. Huff Post mentioned that as a precaution against MERS, Saudi authorities had cut down visa allocation to every country by $20 \%$. Daily Mail used a very aggressive style while reporting MERS concerns. The newspaper compared the virus with Severe Acute Respiratory Syndrome (SARS), and claimed that it could be more dangerous than SARS in which 800 people had lost their lives since 2003. The paper emphasized that the event of Hajj could be a reason for MERS-CoV to spread worldwide. Daily Mail also stated, "There are fears that the combination of so many people combined with the slaughtering of camels, which have been linked to the disease, could increase chances of an outbreak." Another Hajj practice discussed in Huff Post which posed health risk in shaving heads for men. The paper reported that viruses such as Human Immunodeficiency Virus (HIV), hepatitis $\mathrm{B}$ or $\mathrm{C}$, malaria, and other skin diseases could be transferred to pilgrims due to razorsharing. IBTimes, The Guardian and USA Today didn't give any coverage on this issue. In terms of Hajj Management, IBTimes in their articles reported that Saudi Arabian authorities deployed 95,000 security personnel, and installed 1,700 CCTV cameras in Mecca for security purposes of pilgrims during the event. This system also allowed 
the administration to monitor transport and accommodation. The paper admired the latest security system applied by the Saudi government. Los Angeles Times reported that Hajj 2013 was free from any depraved incidents. Here, the paper used a semantic move by mentioning that Hajj was peaceful because pilgrims were fewer than half as compared to last year.

RQ-3: Does the use of vocabulary and slant about Hajj differ in UK and US newspapers discourses?

There was a slight difference in the selection of vocabulary related to Hajj coverage by the print media of both UK and US. The words such as fear, virus, peaceful, Muslim Brotherhood, terrorism, sectarianism, blood, tension, disgrace, violence, infections, health, festival, and sacrifice were used in all the newspapers. The print media of UK adopted more illustrative and approving method while the US press presented critical and probing approach. Also, the UK newspapers remained less belligerent to some extent in contrast to US newspapers. In terms of wordage, the UK papers Daily Mail, The Guardian and IBTimes gave more space by publishing 5,201 words on the Hajj event as compared to US papers Los Angeles Times, USA Today and Huff Post that published 3,711 words. In addition, the overall style of UK press was also less rigid in contrast to US print media.

\section{Conclusion:}

The study indicates that much importance didn't give to the Muslims holy event Hajj in all the newspapers. The Western print media used the discourses of terrorism that mark violence and extremism within Muslim communities. They highlighted the issues of Muslim sects while covering Hajj. The Western countries also isolated their inhabitant Muslims from the 'other' Muslim world. The West usually uses these special tactics to further divide the Muslim world, and to promote the notion of clash of civilizations. ${ }^{57}$ The use of word sectarianism is intended to split Muslims unity, and to divide Arabs on factional and ideological basis. All the papers extensively used the words disgrace, violence, civil war, blood, dispute and division in their discourses. As Miller stated, "words matter, and if you say them often enough and with enough authority, they start to sound true- - even if they are not". ${ }^{58}$ The newspapers of both UK and US specifically focused on the lesser numbers of pilgrims as compared to previous years. Very precisely, they used the words such as 'fear', 'fewer', 'reduced', and 'cut back' to advocate their view of Muslims digits during Hajj.

The Western newspapers also linked the slaughtering of animals with fatal diseases. A study conducted on French pilgrims who had undertaken Hajj 2013. The study indicated that ensuring good public health and controlling spread of infectious diseases during Hajj season were major challenges. The respiratory diseases were main reasons due to which pilgrims were hospitalized during the Hajj. The prominent occurrence of respiratory illness in pilgrims had been revealed in several studies. During Hajj, influenza virus was considered as the main cause of acute respiratory illness. Also, none of the participants were positive for MERS-CoV. ${ }^{59}$ Moreover, the current study results reveal 
that the assortment of themes by print media of UK and US was nearly same. There was no significant difference in promoting any particular theme. The Western newspapers highlighted the importance of Hajj, but at the same time they associated the biggest gathering of Muslims with fears and threats. With every positive connotation, there was a negative nuance. There was tremendous use of semantic moves in discourses as well. Also, much coverage didn't give to the event as it requires. So it could be concluded that newspapers had been tricky while reporting Hajj. The media understand the significance of Hajj to Muslims, but it also draws the attention of the world toward the risks involved in it. This shows the overall agenda of the West toward any Islamic event.

\section{References:}

${ }^{1}$ Hitchcock, Jennifer. "The 5 Pillars of Islam". Verbum 2, no. 2 (2005): 43-50.

${ }^{2}$ Reilly, Geoff, and Wendy Wren. Nelson Thornes Framework English Skills in Non-Fiction 3. Vol. 3, Cheltenham: Nelson Thornes, 2003, 35.

${ }^{3}$ McCleary, Rachel M. "Salvation, Damnation, and Economic Incentives." Journal of Contemporary Religion 22, no. 1 (2007): 49-74.

${ }^{4}$ Fadhlullah, Muhammad Hussain. Clear Guide to Islamic Rulings: Al-Fatawa Al-Wadiha. Beirut: Dar AlMalak, 2001, 573.

${ }^{5}$ Reilly, Geoff, and Wendy Wren. Nelson Thornes Framework English Skills in Non-Fiction 3. Vol. 3, Cheltenham: Nelson Thornes, 2003, 35.

${ }^{6}$ Al-Quran, Surah Al-Imran, 3:96-97

${ }^{7}$ Hasan, Sheeraz. Sheeraz: The Muslim American Dream. Beverly Hills: Tinseltown Media Group, 2006, 76.

${ }^{8}$ Hackett, Conrad, and Brian J. Grim. "The Global Religious Landscape: A Report on the Size and Distribution of the World's Major Religious Groups as of 2010." Washington, D.C.: Pew Research Centre, 2012.

${ }^{9}$ Battuta, Ibn. Tuhfat Al-Nuzzar Fi Ghara'ib Al-Amsar. Beirut: Dar al-Kutub al-Ilmiyy,2002 [ca. 1355].

${ }_{10}$ Wolfe, Michael. "General Introduction." In One Thousand Roads to Mecca: Ten Centuries of Travelers Writing About the Muslim Pilgrimage, edited by Michael Wolfe, xiii-xxxi. New York: Grove Press, 1997.

${ }^{11}$ Clingingsmith, David, Asim Ijaz Khwaja, and Michael Kremer. "Estimating the Impact of the Hajj: Religion and Tolerance in Islam's Global Gathering." The Quarterly Journal of Economics 124, no. 3 (2009): 1133-70.

12 Shuib, Mohd Arif, Shukran Abdul Rahman, and Nor Diana Mohd. Mahudin. "Assessing Psychosocial Elements of Crowds During Hajj: Scale Construction and Content Validation." Paper presented at the 5th National Seminar on Hajj Best Practices on Crowd and Health Issues, Penang, August 27-28 2013.

13 AlGadhi, Saad A. H., and Hani S. Mahmassani. "Simulation of Crowd Behavior and Movement: Fundamental Relations and Application." Transportation Research Record, no. 1320 (1991): 260-68.

${ }^{14}$ Rashid, Najla. "The Economics of Saudi Pilgrimages." Al-Monitor, Retrieved July 16, 2015, from : https://www.al-monitor.com/pulse/tr/business/2012/11/saudi-arabias-pilgrimage-season-economicgains-and-unharvested-potential.html.

15 "Hajj Notes." Saudi Arabia, May 1998, 2.

${ }^{16}$ Wolfe, Michael. "'My Hajj Experience'." Esato, Retrieved December 26, 2013, from: https://www.esato.com/board/viewtopic.php?topic=113811.

${ }^{17}$ Sesay, Isha."Covering the Hajj: A Cnn Reporter's View." Cable News Network, Retrieved 15/8/2013, from: https://edition.cnn.com/2009/WORLD/meast/11/28/hajj.sesay.pilgrimage/index.html?iref=24hours 
${ }^{18}$ Lippmann, Walter. Public Opinion. New York: Macmillan, 1922.

${ }^{19}$ Cohen, Bernard Cecil. The Press and Foreign Policy. Princeton University Press, 1963, 13.

${ }^{20}$ McCombs, Maxwell E., and Donald L. Shaw. "The Agenda-Setting Function of Mass Media." Public Opinion Quarterly 36, no. 2 (1972): 176-87.

${ }^{21}$ Smith, Kim A. "Newspaper Coverage and Public Concern About Community Issues: A Time-Series Analysis." Journalism and Communication Monographs 101 (1987).

${ }^{22}$ Herman, Edward S., and Noam Chomsky. Manufacturing Consent: The Political Economy of the Mass Media. New York: Pantheon Books, 2002.

${ }^{23}$ Miller, David. On Nationality. Oxford: Clarendon Press, 1995.

24 Montgomery, Martin. The Discourse of Broadcast News: A Linguistic Approach. New York: Routledge, 2007, 21.

25 Parenti, Michael. "Monopoly Media Manipulation." Retrieved November 22, 2013, from https://observationdeck.pegasusvideos.com/wp-content/uploads/2019/03/Michael-Parenti-MonopolyMedia-Manipulation.pdf.

${ }^{26}$ Herman, Edward S., and Noam Chomsky. Manufacturing Consent: The Political Economy of the Mass Media. New York: Pantheon Books, 1988.

${ }^{27}$ Huntington, Samuel P. "The Clash of Civilizations." Foreign affairs 72, no. 3 (1993): 22-49.

${ }^{28}$ Abdulla, Rasha A. "Islam, Jihad, and Terrorism in Post-9/11 Arabic Discussion Boards." Journal of Computer-Mediated Communication 12, no. 3 (2007): 1063-81.

${ }^{29}$ Enders, Walter, and Todd Sandler. "After 9/11: Is It All Different Now?". Journal of Conflict Resolution 49, no. 2 (2005): 259-77.

${ }^{30}$ Kellner, Douglas. "9/11, Spectacles of Terror, and Media Manipulation: A Critique of Jihadist and Bush Media Politics." Critical Discourse Studies 1, no. 1 (2004): 41-64.

${ }^{31}$ Knudsen, Are. "Political Islam in the Middle East." Chr. Michelsen Institute, Retrieved September 26, 2013, from https://www.cmi.no/publications/file/1548-political-islam-in-the-middle-east.pdf.

${ }^{32}$ Besova, Asya A., and Skye Chance Cooley. "Foreign News and Public Opinion: Attribute AgendaSetting Theory Revisited." Ecquid Novi 30, no. 2 (2009): 219-42.

${ }^{33}$ Christensen, Christian. "God Save Us from the Islam Cliches." British Journalism Review 17, no. 1 (2006): 65-70.

${ }^{34}$ Al-Zahrani, A. A. "United States Television and Press Coverage of Islam and Muslims." University of Okalahoma, 1988.

${ }^{35}$ Said, Edward W. Covering Islam: How the Media and the Experts Determine How We See the Rest of the World. New York: Vintage Books, 1997.

${ }^{36}$ Pervez, Sadia, and Shazia Saeed. "Portrayal of Muslims and Islam in the Talk Shows of Cnn and Fox News (2007-2009)." Journal of Media Studies 25, no. 2 (2010): 122-40.

${ }^{37}$ Khalid, Muhammad. "The Us Mass Media and Image of Muslim World." Pakistan Perspective 6, no. 2 (2001): 109-24.

${ }^{38}$ Ali, Shahzad, and Muhammad Khalid. "Us Mass Media and Muslim World: Portrayal of Muslims by Newsweek and Time." European Journal of Scientific Research 21, no. 4 (2008): 554-80.

39 Ridouani, Driss. "The Representation of Arabs and Muslims in Western Media." RUTA Comunicación, no. 3 (2011), 2.

${ }^{40}$ Dunn, Kevin M. "Representations of Islam in the Politics of Mosque Development in Sydney." Tijdschrift voor Economische en Sociale Geografie 92, no. 3 (2001): 291-308.

41 Seib, Philip. "The News Media and "the Clash of Civilizations"." In Media and Conflict in the Twenty-First Century, edited by Philip Seib, 217-34. New York: Palgrave Macmillan, 2005.

${ }^{42}$ Ardevol-Abreu, Alberto. "Framing Theory in Communication Research: Origins, Development and Current Situation in Spain." Revista Latina de Comunicación Social 70 (2015): 423-50. 
${ }^{43}$ Baran, Stanley J., and Dennis K. Davis. Mass Communication Theory: Foundations, Ferment, and Future. Stamford: Cengage Learning, 2015, 266.

${ }^{44}$ Entman, Robert M., and Andrew Rojecki. "Freezing out the Public: Elite and Media Framing of the Us Anti-Nuclear Movement." Political Communication 10, no. 2 (1993): 155-73.

${ }^{45}$ McQuail, Denis. Mcquail's Mass Communication Theory. 6th ed. London: Sage Publications, 2010, 383

${ }^{46}$ Entman, Robert M. "Framing Bias: Media in the Distribution of Power." Journal of Communication 57, no. 1 (2007): 163-73.

${ }^{47}$ Entman, Robert M. "Framing Us Coverage of International News: Contrasts in Narratives of the Kal and Iran Air Incidents." Journal of Communication 41, no. 4 (1991): 6-27.

${ }^{48}$ Rahangdale, Ashwini, and A. J. Agrawal. "Information Extraction Using Discourse Analysis from Newswires." International Journal of Information Technology Convergence and Services 4, no. 3 (2014): 21-30.

${ }^{49}$ Hall, Stuart. "Foucault: Power, Knowledge and Discourse." In Discourse Theory and Practice: A Reader, edited by Margaret Wetherell, Stephanie Taylor and Simeon J. Yates, 72-81. London: Sage Publications, 2001, 72.

${ }^{50}$ Schiffrin, Deborah. Approaches to Discourse. Oxford: Blackwell, 1994, 20.

${ }^{51}$ Van Dijk, Teun A. News as Discourse. Hillsdale: Lawrence Erlbaum Associates, 1988.

${ }^{52}$ Van Dijk, Teun A. "Discourse Analysis: Its Development and Application to the Structure of News." Journal of Communication 33, no. 2 (1983): 20-43.

${ }^{53}$ Van Dijk, Teun A."Principles of Critical Discourse Analysis" Discourse \& Society 4, no2 .1993. 249

54 Hamid, Shadi. "The Massacre That Ended the Arab Spring." The Brookings Institution, Retrieved November 22, 2019, from https://www.brookings.edu/blog/markaz/2017/08/15/the-massacre-thatended-the-arab-spring/; Muasher, Marwan. "Is This the Arab Spring 2.0?" Carnegie Endowment for International Peace, Retrieved December 15, 2019, from https://carnegieendowment.org/2019/10/30/isthis-arab-spring-2.0-pub-80220.

55 Black, Ian. "Syria Deaths near 100,000, Says Un - and 6,000 Are Children." Guardian News \& Media, Retrieved March 22, 2014, from https://www.theguardian.com/world/2013/jun/13/death-tollsyrian-conflict-93000; Jolly, David. "Death Toll in Syrian Civil War near 93,000, U.N. Says." The New York Times Company, Retrieved March 14, 2014, from

https://www.nytimes.com/2013/06/14/world/middleeast/un-syria-death-toll.html; Solomon, Erika. "Syria Death Toll Hits Nearly 126,000: Monitoring Group." Reuters, Retrieved March 16, 2014, from https://www.reuters.com/article/us-syria-crisis-toll/syria-death-toll-hits-nearly-126000-monitoringgroup-idUSBRE9B10ES20131202.

${ }^{56}$ Assiri, Abdullah, Allison McGeer, Trish M Perl, Connie S Price, Abdullah A Al Rabeeah, Derek AT Cummings, Zaki N Alabdullatif, et al. "Hospital Outbreak of Middle East Respiratory Syndrome Coronavirus." The New England Journal of Medicine 369, no. 5 (2013): 407-16; Roos, Robert. "Saudi Arabia Announces Three New Mers Cases." CIDRAP, Retrieved November 15, 2013, from https://www.cidrap.umn.edu/news-perspective/2013/08/saudi-arabia-announces-three-new-mers-cases.

${ }^{57}$ Huntington, Samuel P. "The Clash of Civilizations." Foreign affairs 72, no. 3 (1993): 22-49.

58 Miller, Lisa. "'Stealth Jihad' Conveys Paranoia." Newsweek, Retrieved November 12, 2013, from https://www.newsweek.com/stealth-jihad-conveys-paranoia-71697.

59 Benkouiten, Samir, Rémi Charrel, Khadidja Belhouchat, Tassadit Drali, Antoine Nougairede, Nicolas Salez, Ziad A. Memish, et al. "Respiratory Viruses and Bacteria among Pilgrims During the 2013 Hajj." Emerging Infectious Diseases 20, no. 11 (2014): 1821-27. 